\title{
EFFECT OF FREEZING TIME ON THE NUTRITIONAL VALUE OF MYSTUS GULIO (NUNA TENGRA), MYSTUS TENGARA (BAZARI TENGRA) AND MYSTUS CAVASIUS (GHULSHA TENGRA).
}

\author{
M N Siddiqui ${ }^{1}$, P K Biswas ${ }^{1}$, S Ray ${ }^{1,}$ M J Hasan ${ }^{2}$, and M F Reza ${ }^{3}$
}

\begin{abstract}
Three different species of tengra; Nuna tengra (Mystus gulio), Bazri tengra (Mystus tengara), Gholsha tengra (Mystus cavasius) were kept in freezing condition for 20 days to investigate the effect of freezing $\left(-5^{\circ} \mathrm{C}\right)$ time on the nutrient composition (protein, lipid, moisture). The average weight of the sample was 46.5gm, 23.94gm, and 15.48gm for Nuna tengra, Gholsha tengra and Bazri tengra respectively. Samples were collected from Gollamari, Khulna. The amount of protein and lipid reduced while amount of moisture increased with prolongation of freezing time. The amount of moisture for Mystus tengara, Mystus cavasius, Mystus gulio increased from $76.12 \%$ to $78.02 \%$, $75.35 \%$ to $77.25 \%$ and $76.03 \%$ to 78.23\% respectively. At fresh condition the protein content of Mystus tengara, Mystus cavasius, Mystus gulio were $16.26 \%, 15.52 \%$ and $14.80 \%$ and at the end of the experiment protein were $14.97 \%, 13.91 \%$ and $13.43 \%$. At fresh condition the lipid content of Mystus tengara, Mystus cavasius, Mystus gulio were $6.15 \%, 5.98 \%$ and $6.20 \%$ and after twenty days of it's freezing the observed lipid content were $4.9 \%$, $5.37 \%$ and $4.86 \%$. However, at the end of the study, no significant ( $>>0.5)$ difference was observed among different nutrient level due to increasing freezing time.
\end{abstract}

Keywords: Protein, lipid, moisture.

\section{INTRODUCTION}

Among various indigenous fish species of Bangladesh Nuna tengra (Mystus gulio), Bazri tengra (Mystus tengara), Gholsha tengra (Mystus cavasius) are common and popular because of their nutritional value and taste. These are a great source of protein, lipid, minerals etc., which are essential to human development and remedy for various diseases. But availability of this vital source of nutrients largely depends on storage method (Hardy and Smith, 1976.). There are various storage and preservation methods such as freezing, salting, roasting, drying, frying etc. Storage time and temperature are major factors, which affect the rate of loss of quality and shelf life of fish (Whittle, 1997). Moreover different storage methods affect the quality of fish product differently. The present study was conducted to observe the effect of freezing time on the selected fish species.

\section{Sample collection}

\section{MATERIALS AND METHODS}

Some samples of Nuna tengra(total length $1.12 .12 \pm 1.08 \mathrm{~cm})$, Gholsha tengra $(23.94 \pm 0.82 \mathrm{~cm})$ Bazari tehgra $(4.12 \pm 0.26 \mathrm{~cm})$ were collected from local fish market of Khulna city corporation at fresh condition

\footnotetext{
${ }^{1}$ Fisheries and Marine Resource Technology Discipline, Khulna University, Khulna-9208 Email: siddiquiku@yahoo.com

${ }^{2}$ Biochemist, Fish Inspection and Quality Control, Khulna, Department of Fisheries, Ministry of Fisheries and Livestock, Bangladesh. Email: jahidufo@gmail.com

${ }^{3}$ Upazila Fisheries Officer, Department of Fisheries, Ministry of Fisheries and Livestock, Bangladesh.
} 
and transported to the Fish Nutrition Laboratory of Fisheries and Marine Resource Technology Discipline, Khulna University for subsequent experiments.

\section{Sample Preparation}

To prepare the sample for the determination of nutritional composition, the samples were washed thoroughly with the fresh water and adherent water was removed. Then a considerable amount of specimens of each sample were taken and fish muscle was separated from fish body with a sharp knife a. For analysis the nutritional or proximate composition, each experiment was conducted with three replicates.

Proximate composition analysis

Proximate analysis such as moisture, lipid and protein contents were carried out following the methods of AOAC (1984).

\section{RESULTS AND DISCUSSION}

The nutrient composition of Mystus gulio, Mystus tengara and Mystus cavasius in fresh condition and frozen condition at every five days interval are shown in table 1, 2 and 3.

Table 1: Protein, moisture and lipid content of Nuna tengra (Mystus gulio) at different freezing duration. (Compositions are in wet weight basis).

Table 2: Protein, moisture and lipid content of Bazari tengra (Mystus tengara) at different freezing duration.

Table 3: Protein, moisture and lipid content of Gholsha tengra (Mystus cavasius) at different freezing duration.

Moisture

The moisture content of the samples was determined in oven-dry method. In fresh condition the moisture contents of the three species ranged from $75.35 \%$ to $76.12 \%$ at initial stage, among the three species Bazari tengra contains the highest moisture content (76.12\%) it was followed by Gholsha tengra (76.03\%) and Nuna tengra (75.35\%) successively. After twenty days of freezing, the amount of moisture increased gradually. After twenty days their moisture contents ranged from $77.25 \%$ to $78.23 \%$. Nurullah et al (2003) reports that the moisture content of Nuna tengra was $73.67 \%$ at fresh condition and after eight days of freezing the moisture was $76.67 \%$. Present study has affinities with the findings of M. Nurullah et al. (2003). Hossain et al (1999) found the moisture content 75.43\%, 79.45\%, 78.67\% in Gholsha tengra, Nuna tengra and Bazari tengra respectively in fresh condition. But present study has slightly deviated from the result found by Hossain et al (1999). This deviation may occur due to species variation, size, processing method, temperature, season etc (Khan et al 1997). Moreover there is an inverse relation between size and moisture content of the fish (Hossain et al, 1999).

\section{Lipid}

The determined lipid contents of the study on the three species of tengra showed that their lipid contents ranged 5.98\% to $6.20 \%$ in fresh condition. Among them Nuna tengra contained the highest and Gholsha tengra contained the lowest amount of lipid. But in frozen condition these values decreased gradually. The result showed the changing rate of lipid contents of three different species of tengra in frozen condition. Nurullah et al (2003) reported that the average lipid content of Nuna tengra is about 6.28\% in fresh state and after eight days in frozen condition it was found to be around 5.09\%. However, the present study approximately agreed with the amount of lipid found by others. Bligh et al (1959) reported that there is an inverse relation between lipid content of fish and its freezing time. But in all cases all observation did not coincide with the present study on some aspects like the amount of lipid, decreasing rate. This deviation may occur due to size, different body parts of the same fish, seasonal variation, and temperature, oxidation of fat etc. Das (2009) reported that the lipid content of Labeo rohita represents different amount of lipid like at ambient temperature it was $5.21 \%$ and $4.26 \%$, 3.31\% in icing and frozen condition and ambient temperature. 


\section{Protein}

Like other nutrient compositions the protein content of fish is also variable at different condition. The study on nutritional value of different tengra fish revealed that protein content of it varied from $14.80 \%$ to $16.26 \%$ in fresh condition. At the end of the experiment the amount of protein varied from $13.43 \%$ to $14.97 \%$. The result is similar with Nurullah et al (2003). He reported that average protein content of tengra fish was around $16.81 \%$ in its fresh condition and after eight days of its frozen condition it was $14.21 \%$, which indicates slight deterioration of protein level in frozen condition. These findings supported the validity of the present study the determined values differed from others and within different species. This deviation is as usual because protein content of fish varies depending on some factors such as natural feeding habits and availability of feed, fasting during spawning, migration, size of fish etc. (Viswanathan and Mathew, 2000). The reduction in protein level is connected with denaturation of fish protein that is associated with freezing (Reay, 1933).

\section{CONCLUSION}

The study focused on effect of freezing duration on nutritional value specially protein, lipid and moisture. It has some effect on the nutrient compositions of the selected three species, which was taken under experiment. The study showed that there was no significance difference in nutritional value of different tengra species in frozen condition after twenty days. The condition did remain as it was in fresh condition but it was acceptable to all. So it can be concluded that we can use catfishes after preservation at $-5^{\circ} \mathrm{C}$. But we should try to consume the fish in fresh condition as early as possible as quality remain better in earlier stage.

\section{REFERENCES}

AOAC.1984. (Association of Official Analytical Chemists).Official Methods of Analysis, Association of Official Analytical Chemists, 13th Edition, Washington D.C.

Bligh, E. G. and Dyer, W.J. 1959. A rapid method for total lipid extraction and purification. Canadian Journal of Biochemical Physiology. 37: pp:911-917.

Das,K.P., 2009. Effect of ambient temperature, icing and freezing on nutrient composition of Rohu (Labeo rohita),Grass carp (Ctenopharyngodon idella) and Tilapia(Oreochromis mossambica).B.Sc.Thesis, Fisheries and Marine Resources Technology Discipline, Khulna University, Khulna, Bangladesh, pp. 20-30.

Hardy, R., Smith, J. G. M., 1976. The storage of Mackerel (Scomber scoutbrus). Development of histamine and rancidity. Journal of Science of Food and Agriculture, 27: pp. 595-599.

Hossain, M. A., K. Afsana and A. K. M. A. Shah, 1999. Nutritional value of some small indigenous fish species (SIS) of Bangladesh. . Bangladesh J. Fish. Res.,3(1): 77-85.

Khan, M. N. A., M. A. Hossain, M. Kamal and M. N. Islam, 1997. Quality aspects of some exportable and dried fishery products of Bangladesh. Bangladesh J. Fish. Res., 1(2): 83-90.

Nurullah, M., Kamal, M., Wahab, M. A., Islam, M.N., Ahasan, C. T., and Thilsted, S. H., 2003.Nutritional quality of some small indigenous fish species of Bangladesh. pp: 151-158.

Reay, G.A., 1933. The influence of freezing temperature on hadock's muscle, JSOC Chem. Ind. London 52: pp.256.

Viswanathan, P. G. N. and Mathew, S., 2000. Biochemical composition of fish and shellfish. Central Institute of Fisheries Technology, Cochin. CIFT Technology Advisory Series. pp. 4-7.

Whittle, K. J., 1997. Opportunities for improving the quality of fisheries products. In: Luten JB, Borrosen T, Oehlenschlager J (Eds), Seafood from producer to consumer, integrated approach to quality. Proceedings of the International Seafood Conference on the $25^{\text {th }}$ anniversary of WEFTA, Netherlands, 13-16th November 1995, Elsevier, Amsterdam, pp. 549-560. 


\section{TABLES:}

Table 1: Protein, moisture and lipid content of Nuna tengra (Mystus gulio) at different freezing duration. (Compositions are in wet weight basis).

\begin{tabular}{|l|c|c|c|}
\hline \multirow{2}{*}{ Freezing duration } & \multicolumn{3}{|c|}{ Nutrient composition } \\
\cline { 2 - 4 } & Protein (\%) & Moisture (\%) & Lipid (\%) \\
\hline 0 day (fresh condition) & 14.80 & 76.03 & 6.20 \\
\hline $5^{\text {th }}$ & 14.11 & 77.62 & 5.73 \\
\hline $10^{\text {th }}$ & 13.68 & 77.89 & 5.27 \\
\hline $15^{\text {th }}$ & 13.51 & 78.12 & 5.13 \\
\hline $20^{\text {th }}$ & 13.43 & 78.23 & 4.86 \\
\hline
\end{tabular}

Table 2: Protein, moisture and lipid content of Bazari tengra (Mystus tengara) at different freezing duration.

\begin{tabular}{|l|c|c|c|}
\hline \multirow{2}{*}{ Freezing duration } & \multicolumn{3}{|l|}{ Nutrient composition } \\
\cline { 2 - 4 } & Protein (\%) & Moisture (\%) & Lipid (\%) \\
\hline 0 day (fresh condition) & 16.26 & 76.12 & 6.15 \\
\hline $5^{\text {th }}$ & 15.93 & 76.64 & 5.83 \\
\hline $10^{\text {th }}$ & 15.46 & 77.06 & 5.62 \\
\hline $15^{\text {th }}$ & 15.12 & 77.89 & 5.23 \\
\hline $20^{\text {th }}$ & 14.97 & 78.02 & 4.9 \\
\hline
\end{tabular}

Table 3: Protein, moisture and lipid content of Gholsha tengra (Mystus cavasius) at different freezing duration.

\begin{tabular}{|l|c|c|c|}
\hline \multirow{2}{*}{ Freezing duration } & \multicolumn{3}{|c|}{ Nutrient composition } \\
\cline { 2 - 4 } & Protein (\%) & Moisture (\%) & Lipid (\%) \\
\hline 0 day (fresh condition) & 15.52 & 75.35 & 5.98 \\
\hline $5^{\text {th }}$ & 14.36 & 76.79 & 5.61 \\
\hline $10^{\text {th }}$ & 14.20 & 76.98 & 5.50 \\
\hline $15^{\text {th }}$ & 13.95 & 77.22 & 5.43 \\
\hline $20^{\text {th }}$ & 13.91 & 77.25 & 5.37 \\
\hline
\end{tabular}

